\title{
DYNAMIC ANALYSIS OF FGM RHOMBIC PLATES WITH A VARIATION IN THE MASS
}

\author{
DINAMIČNA ANALIZA FGM ROMBSKIH PLOŠČ RAZLIČNIH \\ MAS
}

\author{
Md Irfan Ansari', Ajay Kumar'1, Danuta Barnat-Hunek², Przemyslaw Brzyski²*, \\ Wojciech Andrzejuk ${ }^{3}$ \\ ${ }^{1}$ National Institute of Technology Patna, Department of Civil Engineering, Patna, Bihar, India \\ ${ }^{2}$ Lublin University of Technlogy, Faculty of Civil Engineering and Architecture, Department of Construction, Nadbystrzycka 40, 20-618 \\ Lublin, Poland \\ ${ }^{3}$ Pope John Paul II State School of Higher Education in Biała Podlaska, Faculty of Economics and Engineering, 95/97 Sidorska, 21-500 Biała \\ Podlaska, Poland \\ p.brzyski@pollub.pl
}

Prejem rokopisa - received: 2018-04-06; sprejem za objavo - accepted for publication: 2018-06-14

doi:10.17222/mit.2018.071

\begin{abstract}
A dynamic analysis of shear-deformable rhombic plates from functionally graded material (FGM) with a variation in the mass is presented. The present mathematical model incorporates a realistic cubic variation of the thickness coordinate in displacement fields. Due to the parabolic variation of the transverse shear strains in the thickness, the shear-correction factor is eliminated. The finite-element formulation of the present mathematical model is done using a two-dimensional $\mathrm{C}^{0}$ element with seven nodal unknowns. A computer code is written for the present finite-element formulation. The material properties vary in the thickness direction of the FGM rhombic plate at any point according to the Mori-Tanaka scheme. The accuracy of the formulation is demonstrated by comparing it with suitable examples from the literature. This is the first attempt at a dynamic study of FGM rhombic plates with a variation in the mass and with various volume-fraction indices, thickness ratios and boundary constraints. Keywords: functionally graded material, finite-element method, cutouts, additional mass
\end{abstract}

V članku je predstavljena dinamična analiza strižno deformiranih rombskih plošč iz materiala s funkcionalno porazdeljenimi lastnostmi (FGM, angl.: functionally graded material) različnih mas. Predstavljeni matematični model vključuje realistične kubične variacije koordinat debeline v premičnem polju. Zaradi paraboličnih variacij prečnih strižnih deformacij v debelini je eliminiran korekcijski faktor striga. Formulacijo z metodo končnih elementov predstavljenega matematičnega modela so avtorji izvršili $\mathrm{z}$ uporabo dvodimenzionalnega $\mathrm{C}^{0}$ elementa s sedmimi vozliščnimi neznankami. Napisali so računalniško kodo za predstavljeno formulacijo končnih elementov. Materialne lastnosti se spreminjajo v smeri debeline rombske FGM plošče v vsaki točki skladno s shemo Tanake. Natančnost formulacije je v članku predstavljena s primerjavo primernih primerov iz literature. To je prvi pristop k dinamičnemu študiju rombskih FGM plošč s spremenljivo maso in s spreminjajočimi kazalci volumskim deležev, razmerji debeline in mejnimi omejitvami.

Ključne besede: material s funkcionalno porazdeljenimi lastnostmi, metoda končnih elementov, izrezi, dodatna masa

\section{INTRODUCTION}

In recent years, plates made of FGMs have gained considerable attention in civil, aeronautical, mechanical and marine engineering. A variation in the mass is achieved using a cutout and additional mass in the present model. Plates with cutouts are used to modify the weight of a structural member, provide ventilation, attain the appropriate connection between structural components or alter the resonant frequency of a structure. The additional mass is generally used to reduce the fundamental frequency to a desired value. Reddy ${ }^{1}$ evaluated the static behaviour of FGM plates based on a third-order shear-deformation theory (TSDT). Abrate ${ }^{2}$ studied the complications of a free vibration analysis of FGM plates using a classical laminated-plate model. The threedimensional solution for the vibration problem of a plate from functionally graded material was presented by Uymaz \& Aydogdu ${ }^{3}$ under various boundary conditions. Matsunaga ${ }^{4}$ used a two-dimensional higher-order defor- mation theory and Zhao et al. ${ }^{5}$ implemented a first-order shear-deformation theory (FSDT) while Fares et al. ${ }^{6}$ used a refined two-dimensional theory to estimate the vibrations of FG plates under different boundary conditions. The bending behaviour of an FGM plate using a higherorder shear-deformation theory was studied by Taj et al. ${ }^{7}$ The finite-element formulation based on a third-order shear-deformation theory was used by Taj and Chakrabarti ${ }^{8}$ to analyse the static and dynamic behaviour of skew plates from functionally graded material. Asemi et al. ${ }^{9}$ utilized the principle of minimum energy and Rayleigh-Ritz energy method for static and dynamic analyses of FGM skew plates. Most of the earlier dynamic analyses of the plates with cutouts were limited to isotropic plates ${ }^{10-11}$ and Reddy ${ }^{12}$ reported on a laminated composite plate with a cutout. Huang and Sakiyama ${ }^{13}$ used a numerical method for the analysis of free vibrations of square plates with different types of cutouts. The thermal effect on free vibrations of FGM non-uni- 
form straight-sided plates with different shapes of cutouts was investigated by Janghorban and Zare. ${ }^{14}$

Most of the finite-element (FE) software is based on FSDT, which is not suitable for moderately thick plates because FSDT requires the shear-correction factor. In the present analysis, a parabolic transverse-shear-strain deformation across the thickness is taken and consequently the need for the shear-correction factor is eliminated. From the literature review, it is clear that no result of a dynamic analysis of FGM rhombic plates with a variation in the mass is available. Hence, in the present study, an attempt was made to carry out a dynamic analysis of FGM rhombic plates with a cutout and additional mass.

\section{MATERIALS AND METHODS}

\subsection{Effective material properties}

An FGM plate is a combination of two differently dispersed constituents; its material is macroscopically isotropic and material properties gradually change only in the thickness direction. The effective property of the FGM plate at any height $x_{3}$ can be expressed as

$$
\begin{gathered}
P\left(x_{3}\right)=P_{\mathrm{c}} V_{\mathrm{c}}\left(x_{3}\right)+P_{\mathrm{m}} V_{\mathrm{m}}\left(x_{3}\right) \\
V_{\mathrm{c}}\left(x_{3}\right)=\left(\frac{1}{2}+\frac{x_{3}}{h}\right)^{n},(0 \leq n \leq \infty) \text { and } V_{\mathrm{c}}\left(x_{3}\right)+V_{\mathrm{m}}\left(x_{3}\right)=1(2)
\end{gathered}
$$

where $P_{\mathrm{m}}$ and $P_{\mathrm{c}}$ denote the material properties of the metal and ceramic, respectively, $V_{\mathrm{c}}$ and $V_{\mathrm{m}}$ are called the volume fractions of ceramic and metallic constituents, respectively, and $n$ is known as the volume fraction index.

According to the Mori-Tanaka scheme, ${ }^{15}$ the effective bulk modulus $(B)$, the effective shear modulus $(G)$, the modulus of elasticity $(E)$ and Poisson's ratio $(v)$ can be calculated at any point within the FGM plate.

\subsection{Mathematical formulation}

The geometry of the FGM plate with a cutout used in present study is shown in Figure 1. The length of the plate is taken as $a$, the width is $b$ and the total thickness is $h$. The middle section of the plate from functionally graded material is taken as the reference. The displacement field for the FGM rhombic plate is considered to derive the mathematical model based on Reddy ${ }^{1}$ :

$$
\begin{aligned}
& u\left(x_{1}, x_{2}, x_{3}\right)=u_{0}+x_{3} \theta_{x_{1}}-\frac{4 x_{3}^{3}}{3 h^{2}}\left(\theta_{x_{1}}+w_{0, x_{1}}\right) \\
& u\left(x_{1}, x_{2}, x_{3}\right)=v_{0}+x_{3} \theta_{x_{2}}-\frac{4 x_{3}^{3}}{3 h^{2}}\left(\theta_{x_{2}}+w_{0, x_{2}}\right) \\
& w\left(x_{1}, x_{2}, x_{3}\right)=w_{0}
\end{aligned}
$$

where $u, v$ and $w$ are displacements of any generic point in the plate geometry, $u_{0}, v_{0}$ and $w_{0}$ are displacements at the mid-plane and $\theta_{x 1}, \theta_{x 2}$ are the bending rotations defined at the mid-plane about the $x_{2}$ and $x_{1}$ axes, res-

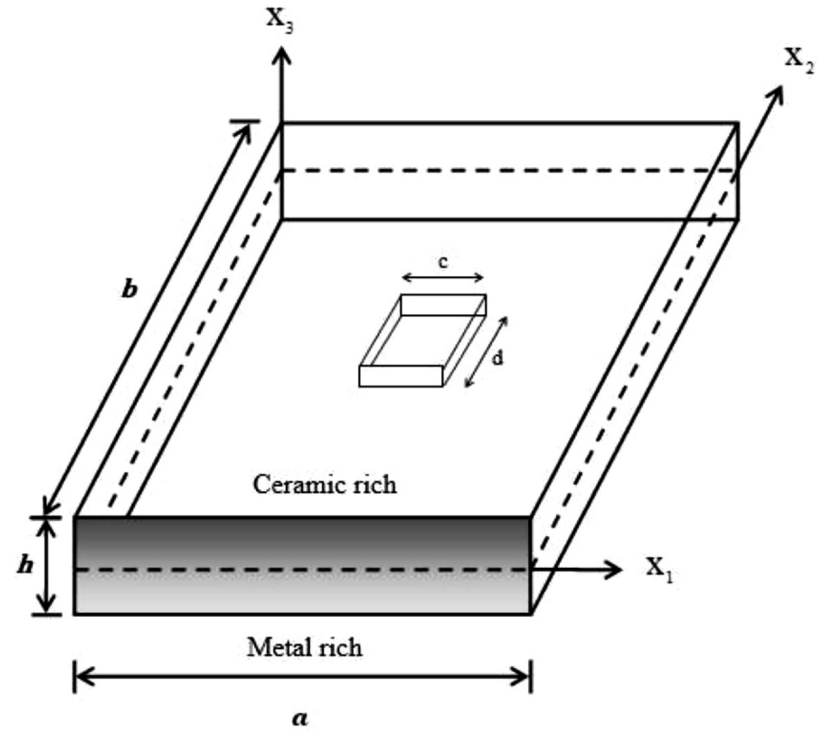

Figure 1: Geometry of an FGM plate with a cutout having a zero skew angle with the $x_{2}$ axis

pectively. For the condition of field the variables are continuous within the element, while for the $\mathrm{C}^{0}$ continuity problem the out-of-plane derivatives are substituted by incorporating the following relations in Equation (3):

$$
\psi_{x_{1}}=\left(\theta_{x_{1}}+w_{0, x_{1}}\right), \psi_{x_{2}}=\left(\theta_{x_{2}}+w_{0, x_{2}}\right)
$$

The strain-displacement relationships can be expressed as

$\left\{\begin{array}{l}\varepsilon_{x_{1}} \\ \varepsilon_{x_{2}} \\ \psi_{x_{1} x_{2}}\end{array}\right\}=\left\{\begin{array}{l}u_{0, x_{1}} \\ v_{0, x_{2}} \\ u_{0, x_{2}}+v_{0, x_{1}}\end{array}\right\}+x_{3}\left\{\begin{array}{l}\theta_{x_{1}, x_{1}} \\ \theta_{x_{2}, x_{2}} \\ \theta_{x_{1}, x_{2}}+\theta_{x_{2}, x_{1}}\end{array}\right\}+$

$+\frac{4 x_{3}^{3}}{3 h^{2}}\left\{\begin{array}{l}\psi_{x_{1}, x_{1}} \\ \psi_{x_{2}, x_{2}} \\ \psi_{x_{1}, x_{2}}+\psi_{x_{2}, x_{1}}\end{array}\right\}$

$\left\{\begin{array}{l}\gamma_{x_{2}, x_{3}} \\ \gamma_{x_{3}, x_{1}}\end{array}\right\}=\left\{\begin{array}{l}w_{0, x_{2}}+\theta_{x_{2}} \\ w_{0, x_{1}}+\theta_{x_{1}}\end{array}\right\}-\frac{4 x_{3}^{3}}{3 h^{2}}\left\{\begin{array}{l}\psi_{x_{2}} \\ \psi_{x_{1}}\end{array}\right\}$

Further, the expression of the strain vector $\varepsilon$ can be correlated with the displacement vector $\delta$ using the following relationship:

$$
\{\varepsilon\}=[B]\{\delta\}
$$

where $B$ is known as the strain-displacement matrix, involving the derivatives of shape-function terms.

\subsection{Finite-element formulation}

\subsubsection{Element description}

A nine-nodded $\mathrm{C}^{0}$ isoparametric Lagrangian element is utilized in the present investigation. It has a total of sixty-three degrees of freedom and each node has seven degrees of freedom. 


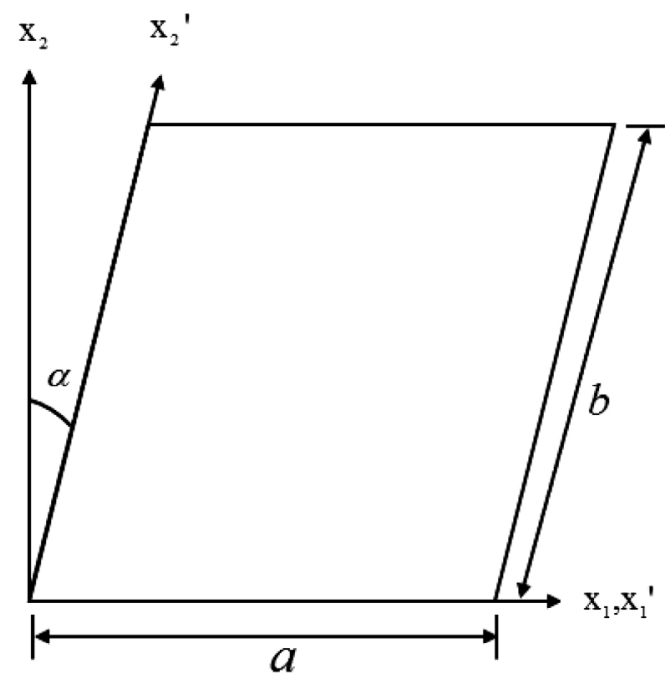

Figure 2: Plan of a plate with a skew angle $(\alpha)$ with the $x_{2}$ axis

\subsubsection{Skew boundary transformation}

For the rhombic plate shown in Figure 2, the edges of the boundary elements are not parallel to the global axes of the rhombic plate. Hence, the transformation matrix $T$ is required to transform the element matrices from the global to the local axes.

Transformation matrix

$$
[T]=\left(\begin{array}{ccccccc}
c & -s & 0 & 0 & 0 & 0 & 0 \\
s & c & 0 & 0 & 0 & 0 & 0 \\
0 & 0 & 1 & 0 & 0 & 0 & 0 \\
0 & 0 & 0 & c & -s & 0 & 0 \\
0 & 0 & 0 & s & c & 0 & 0 \\
0 & 0 & 0 & 0 & 0 & c & -s \\
0 & 0 & 0 & 0 & 0 & s & c
\end{array}\right)
$$

where $c=\cos \alpha, s=\sin \alpha$ and $\alpha$ is the skew angle of the plate.

\subsubsection{Governing equation for the free-vibration analysis}

The acceleration at any point within the element may be expressed in terms of the mid-surface displacement parameters $\left(u_{0}, v_{0}, w_{0}\right)$ as

$$
\{f\}=\frac{\partial^{2}}{\partial t^{2}}\{\bar{f}\}=-\omega^{2}\left\{\begin{array}{l}
u \\
v \\
w
\end{array}\right\}=-\omega^{2}[F]\{f\}
$$

where the vector $f$ represents the nodal unknowns and is of the $7 \times 1$ order, containing the terms of Equation (3).

The vector $f$ is decoupled into the matrix $C$ that contains the shape functions $\left(N_{i}\right)$ and the global displacement vector $\delta$.

$$
\{f\}=[C]\{\delta\}
$$

By utilizing Equations (8) and (9), the mass matrix of an element may be expressed as

$$
[m]=\iint_{A}[C]^{T}[L][C] \mathrm{d} A
$$

where the expression of the matrix $L$ can be written as

$$
[L]=\int_{A} \rho[F]^{T}[F] \mathrm{d} z
$$

where $\rho$ is the density of the FGM estimated from Equation (1). Hence, the governing equation for the free-vibration analysis becomes

$$
\left([K]-\omega^{2}[M]\right)\{X\}=\{0\}
$$

where $M$ and $K$ are the mass matrix and linear-stiffness matrix, respectively. The solution of the above equation (eigenvalue problem) provides the vibration characteristics, that is, the frequency parameters for the free vibration of the functionally graded rhombic plate.

\section{RESULTS AND DISCUSSION}

The vibration behaviour of the FGM rhombic plates with additional mass and cutouts was analysed considering different combinations of ceramic and metal constituents, the boundary condition, skew angle, cutout size and additional mass with several geometric parameters. An FE code was implemented based on the present formulation. Seven unknowns per node for the present model were utilized for the nine-nodded isoparametric elements to discretize the FGM rhombic plate.

The non-dimensional quantities used are:

The non-dimensional frequency parameter

$$
\bar{\omega}=\frac{\omega a^{2}}{h \sqrt{\frac{\rho_{\mathrm{c}}}{E_{\mathrm{c}}}}}
$$

The non-dimensional additional mass

$$
\bar{M}=\frac{M}{\rho_{\mathrm{c}} h a^{2}}
$$

The boundary conditions used in the present study are as follows:

Clamped and simply supported (CCSS):

$$
\begin{aligned}
& \text { At } x_{1}=0, a \quad u=v=w=\theta_{x_{1}}=\theta_{x_{2}}=\psi_{x_{1}}=\psi_{x_{2}}=0 \\
& \text { At } x_{2}=0, b \quad u=w=\theta_{x_{1}}=\psi_{x_{1}}=0 \\
& \text { Clamped and free (CCFF): } \\
& \text { At } x_{1}=0, \mathrm{a} \\
& \text { At } x_{2}=0, \mathrm{~b} \quad u=v=w=\theta_{x_{1}}=\theta_{x_{2}}=\psi_{x_{1}}=\psi_{x_{2}} \neq 0
\end{aligned}
$$

\subsection{Convergence and validation}

Since there is no study of a free-vibration analysis of an FGM plate with additional mass available, a comparison with an FGM plate without additional mass was made. The material properties of the FGM components specified at the normal temperature and utilized for the calculation used in present study are provided below. 
FGM $\left(\mathrm{Al} / \mathrm{Al}_{2} \mathrm{O}_{3}\right): E_{\mathrm{c}}=380 \mathrm{GPa}, E_{\mathrm{m}}=70 \mathrm{GPa}, v_{\mathrm{c}}=0.3$, $v_{\mathrm{m}}=0.3, \rho_{\mathrm{c}}=3800 \mathrm{~kg} / \mathrm{m}^{3}, \rho_{\mathrm{m}}=2707 \mathrm{~kg} / \mathrm{m}^{3}$

Table 1 shows a convergence-and-validation study of an FGM plate without additional mass where the present finite-element formulation is validated with a threedimensional solution by Uymaz and Aydogdu ${ }^{3}$. It is noticed that a $20 \times 20$ mesh is satisfactory for the free-vibration analysis of the FGM plate. For various thickness ratios, the present results compare well with the previous results. The dimensionless frequency parameter of an FGM rhombic plate made of SUS304 and $\mathrm{Si}_{3} \mathrm{~N}_{4}$ is shown in Table 2. The side-to-thickness ratio $a / h=10$ and skew angles $\alpha=15^{\circ}$ and $30^{\circ}$ were considered. For various volume-fraction indices, the non-dimensional frequency parameter applying up to 4 modes was compared with the result obtained by Zhao et al. ${ }^{5}$ and reasonable agreement between the results was found. The numerical results for the non-dimensional frequency parameter of a simply supported isotropic plate for $v=0.3$ and $a / h=50$ are presented in Table 3. The presented results were checked against those obtained by Ali and Atwal ${ }^{11}$; we

Table 1: Convergence of linear frequency with the volume-fraction index for an FGM $\left(\mathrm{Al} / \mathrm{ZrO}_{2}\right)$ square plate under the clamped-boundary condition

\begin{tabular}{|c|c|c|c|c|c|c|c|}
\hline \multirow{2}{*}{$a / h$} & \multirow{2}{*}{$\begin{array}{l}\text { Mesh } \\
\text { size }\end{array}$} & \multicolumn{6}{|c|}{$n$} \\
\hline & & 0 & 0.5 & 1 & 2 & 5 & 10 \\
\hline \multirow{6}{*}{10} & $4 \times 4$ & 3.3290 & 2.9372 & 2.8051 & 2.7061 & 2.6063 & 2.5284 \\
\hline & $8 \times 8$ & 3.3026 & 2.9131 & 2.7824 & 2.6850 & 2.5867 & 2.5094 \\
\hline & $12 \times 12$ & 3.3010 & 2.9116 & 2.7837 & 2.6836 & 2.5854 & 2.5082 \\
\hline & $16 \times 16$ & 3.3006 & 2.9113 & 2.7806 & 2.6834 & 2.5852 & 2.5080 \\
\hline & $18 \times 18$ & 3.3005 & 2.9112 & 2.7805 & 2.6833 & 2.5851 & 2.5079 \\
\hline & $20 \times 20$ & 3.3005 & 2.9112 & 2.7805 & 2.6833 & 2.5851 & 2.5079 \\
\hline & $\begin{array}{c}\text { Uymaz } \\
\text { and } \\
\text { Aydogdu }^{3}\end{array}$ & 3.3496 & 3.0249 & 2.8809 & 2.7658 & 2.6645 & 2.5923 \\
\hline
\end{tabular}

Table 2: Comparison of frequency parameters for an FGM $\left(\mathrm{SuS}_{3} \mathrm{O}_{4} / \mathrm{Si}_{3} \mathrm{~N}_{4}\right)$ clamped rhombic plate $(a / h=10, a / b=1)$

\begin{tabular}{|c|c|c|c|c|c|}
\hline \multirow{2}{*}{$n$} & \multirow{2}{*}{ Mode } & \multicolumn{4}{|c|}{ Skew angle $(\alpha)$} \\
\cline { 3 - 6 } & & \multicolumn{2}{|c|}{$15^{\circ}$} & \multicolumn{2}{c|}{$30^{\circ}$} \\
\cline { 3 - 6 } & & Present & Zhao et al. $^{5}$ & Present & Zhao et al. $^{5}$ \\
\hline \multirow{4}{*}{1} & 1 & 6.2833 & 6.2043 & 7.4459 & 7.3546 \\
\cline { 2 - 6 } & 2 & 11.2783 & 11.1789 & 12.3863 & 12.2774 \\
\cline { 2 - 6 } & 3 & 12.6163 & 12.5160 & 15.4895 & 15.3673 \\
\cline { 2 - 6 } & 4 & 16.1050 & 15.9364 & 17.2137 & 17.0489 \\
\hline
\end{tabular}

Table 3: Comparison of frequency parameters for a simply supported square plate with a square cutout at the centre

\begin{tabular}{|c|c|c|c|}
\hline Cutout size & $\begin{array}{c}\text { Ali and } \\
\text { Atwal }^{11} \\
\text { FEM }\end{array}$ & $\begin{array}{c}\text { Ali and } \\
\text { Atwal }^{11} \\
\text { Rayleigh's } \\
\text { method }\end{array}$ & $\begin{array}{c}\text { Present } \\
\text { (TSDT) }\end{array}$ \\
\hline No cutout & 19.816 & 19.739 & 19.7133 \\
\hline $0.1 \mathrm{a} \times 0.1 \mathrm{a}$ & 18.491 & 19.427 & 19.4282 \\
\hline $0.2 \mathrm{a} \times 0.2 \mathrm{a}$ & 18.446 & 19.274 & 19.1095 \\
\hline $0.3 \mathrm{a} \times 0.3 \mathrm{a}$ & 19.126 & 19.549 & 19.4235 \\
\hline $0.4 \mathrm{a} \times 0.4 \mathrm{a}$ & 20.650 & 20.705 & 20.7270 \\
\hline
\end{tabular}

found the results were close, confirming a high accuracy of the present model.

\subsection{Results and discussion}

Table 4 shows the effect of the non-dimensional additional mass and volume-fraction index $(n)$ on the non-dimensional frequency parameter for the simply supported (SSSS) FGM rhombic plate. The results are computed for $a / h=10, a / b=1$ and $\bar{M}=0.5,1,2$. It is observed that the rise in the volume fraction $\left(V_{\mathrm{c}}=0\right.$ to 1$)$ results in a decrease in the dimensionless frequency. The reason for this is the fact that an FGM plate with a larger volume fraction (near to 1) implies that the plate has a smaller ceramic component and thus the stiffness is reduced. Apart from this, the dimensionless-frequency parameter increases with an increase in the skew angle. Due to the fact that the increase in the skew angle reduces the length of the shorter diagonal, which leads to an enhancement in the stiffness of the rhombic plate, the frequency increases.

Table 4: Variation in the frequency parameter for a simply supported FGM rhombic plate with additional mass $(a / b=1, a / h=10)$

\begin{tabular}{|c|c|c|c|c|c|}
\hline \multirow{3}{*}{$n$} & $\bar{M}$ & \multicolumn{4}{|c|}{ Skew angle } \\
\cline { 2 - 6 } & & $15^{\circ}$ & $30^{\circ}$ & $45^{\circ}$ & $60^{\circ}$ \\
\hline \multirow{3}{*}{ Ceramic } & 0.5 & 3.2506 & 3.6066 & 4.3476 & 5.8281 \\
\cline { 2 - 6 } & 1 & 2.4517 & 2.6919 & 3.1919 & 4.1979 \\
\cline { 2 - 6 } & 2 & 1.7940 & 1.9580 & 2.3008 & 2.9959 \\
\hline \multirow{4}{*}{0.2} & 0.5 & 2.6773 & 2.9714 & 3.5869 & 4.8309 \\
\cline { 2 - 6 } & 1 & 2.0159 & 2.2149 & 2.6314 & 3.4789 \\
\cline { 2 - 6 } & 2 & 1.4738 & 1.6099 & 1.8961 & 2.4825 \\
\hline \multirow{4}{*}{1} & 0.5 & 2.3343 & 2.5889 & 3.1220 & 4.2024 \\
\cline { 2 - 6 } & 1 & 1.7531 & 1.9255 & 2.2869 & 3.0240 \\
\cline { 2 - 6 } & 2 & 1.2798 & 1.3979 & 1.6465 & 2.1572 \\
\hline & 0.5 & 2.0933 & 2.3180 & 2.7873 & 3.7336 \\
\cline { 2 - 6 } & 1 & 1.5671 & 1.7192 & 2.0374 & 2.6837 \\
\hline \multirow{3}{*}{10} & 2 & 1.1419 & 1.2462 & 1.4652 & 1.9133 \\
\cline { 2 - 6 } & 0.5 & 1.6393 & 1.8046 & 2.1445 & 2.8105 \\
\cline { 2 - 6 } & 1 & 1.2156 & 1.3272 & 1.5574 & 2.0129 \\
\hline \multirow{3}{*}{ Metal } & 2 & 0.8810 & 0.9576 & 1.1162 & 1.4325 \\
\cline { 2 - 6 } & 0.5 & 1.4470 & 1.5962 & 1.9065 & 2.5281 \\
\cline { 2 - 6 } & 2 & 1.0730 & 1.1742 & 1.3852 & 1.8113 \\
\hline
\end{tabular}

Figure 3 illustrates the effect of additional mass on the frequency parameter of the FGM rhombic plate under various boundary conditions and Figure 4 shows the effects of side-to-thickness ratios on the frequency parameter. It can be noticed that the value of the dimensionless frequency parameter decreases with an increase in the additional mass. It is interesting to notice that a very low effect of additional mass is observed for the CFCF (clamped and free) type of boundary condition. It is also noticed that the frequency parameter increases when constraints on the boundaries increase. The CCCC type exhibits the highest frequency parameter while the CFCF type exhibits the lowest frequency parameter 


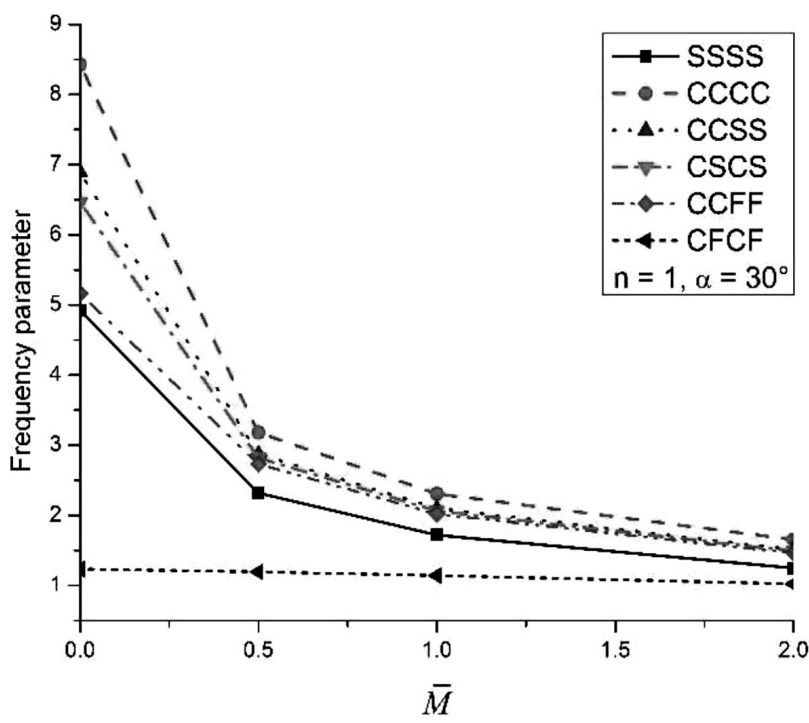

Figure 3: Variation in the frequency parameter with non-dimensional additional mass for the FGM rhombic plate for $a / h=10$

among all combinations of the end supports and all the skew angles. The dimensionless frequency parameter for the other end supports (CCSS, CSCS, CCFF and CFCF) is between CCCC and CFCF. The frequency parameter increases with an increase in the $a / h$ ratio up to $a / h=50$; beyond that no significant change in the frequency parameter is noticed. The variation in the non-dimensional frequency for the simply supported FGM rhombic plate with a central cutout is presented in Table 5. The results are computed for $a / h=10$ and $a / b=1$. The dimensionless frequency parameter first decreases, then it increases with the increase in the cutout size at the centre. The increase in the cutout size results in an increase in the frequency parameter of the FGM rhombic plate due to the reduction in mass. However, this is not

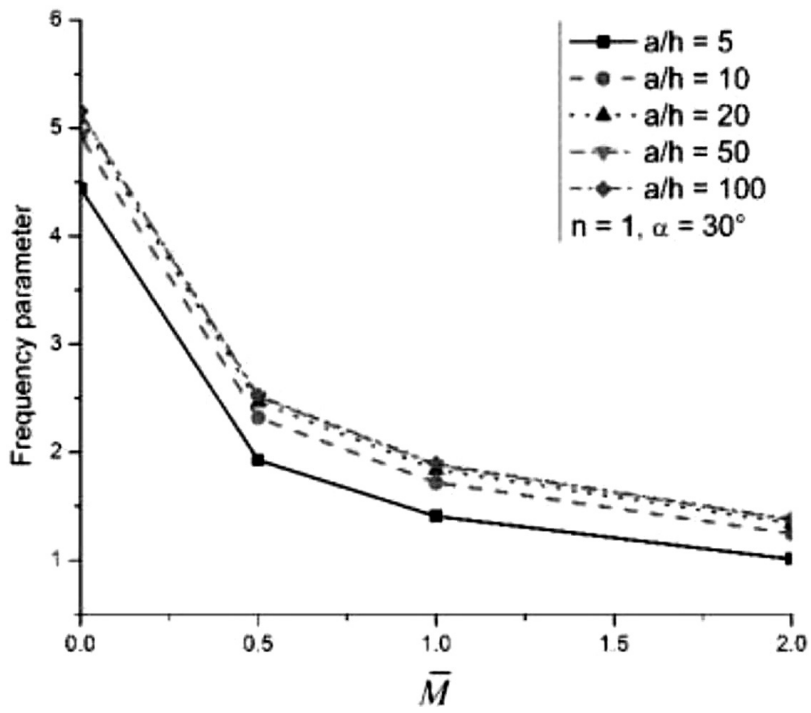

Figure 4: Variation in the frequency parameter with non-dimensional additional mass for the simply supported FGM rhombic plate

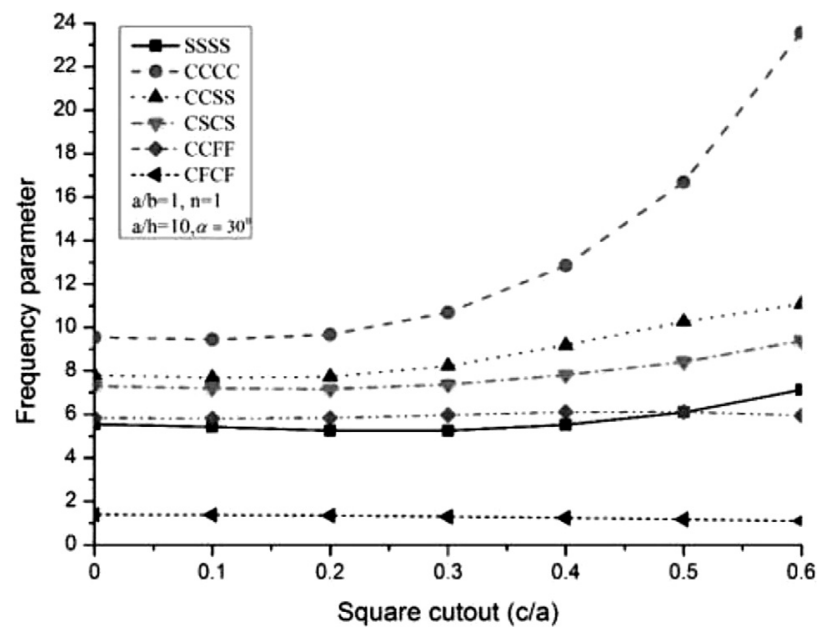

Figure 5: Variation in the frequency parameter with the cutout size for the FGM rhombic plate for various boundary conditions

always the case due to the fact that the position and size of the cutout change the mass as well as the flexure rigidity of the FGM plate.

Figure 5 describes the variation in the frequency parameter with the cutout size for the FGM rhombic plate under various boundary conditions. It can be seen that the increasing boundary constraints increase the non-dimensional frequency parameter as expected. It is also noticed that the dimensionless-frequency parameter increases with an increase in the cutout size for SSSS, CCCC, CCSS, CSCS, but not for the CFCF boundary condition. Figure 6 shows the deviation in the nondimensional frequency parameter of the FGM rhombic clamped plate with the side-to-thickness ratio for different cutout sizes. The results are computed for various cutout sizes, keeping $a / b=1$ and $n=1$.

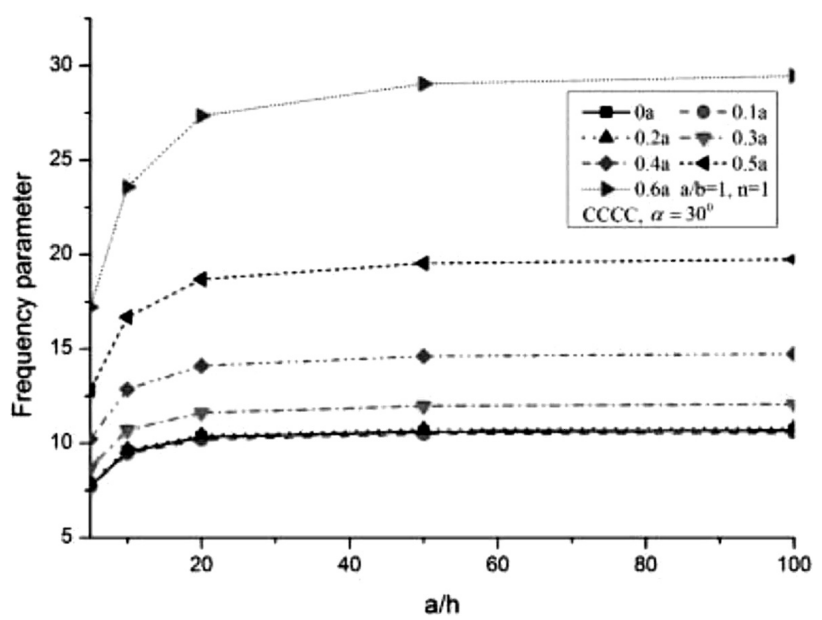

Figure 6: Variation in the frequency parameter with the side-to-thickness ratios for the FGM rhombic plate with a cutout 
Table 5: Variation in the frequency parameter with the cutout size for the simply supported FGM rhombic plate

\begin{tabular}{|c|c|c|c|c|c|}
\hline \multirow{2}{*}{$n$} & \multirow{2}{*}{$c / a=d / a$} & \multicolumn{4}{|c|}{ Skew angle } \\
\hline & & $15^{\circ}$ & $30^{\circ}$ & $45^{\circ}$ & $60^{\circ}$ \\
\hline \multirow{4}{*}{ Ceramic } & 0.1 & 5.9877 & 7.0664 & 9.6664 & 16.5884 \\
\hline & 0.2 & 5.8644 & 6.8498 & 9.1699 & 15.1024 \\
\hline & 0.3 & 5.9319 & 6.8652 & 9.0272 & 14.4389 \\
\hline & 0.4 & 6.2847 & 7.2101 & 9.3307 & 11.4766 \\
\hline \multirow{4}{*}{0.2} & 0.1 & 5.0072 & 5.9121 & 8.0967 & 13.9318 \\
\hline & 0.2 & 4.9085 & 5.7363 & 7.6878 & 12.6871 \\
\hline & 0.3 & 4.9690 & 5.7536 & 7.5728 & 12.1298 \\
\hline & 0.4 & 5.2677 & 6.0461 & 7.8302 & 9.9944 \\
\hline \multirow{4}{*}{0.5} & 0.1 & 4.4485 & 5.2523 & 7.1928 & 12.3751 \\
\hline & 0.2 & 4.3604 & 5.0956 & 6.8284 & 11.2642 \\
\hline & 0.3 & 4.4136 & 5.1102 & 6.7245 & 10.7632 \\
\hline & 0.4 & 4.6781 & 5.3687 & 6.9505 & 9.0363 \\
\hline \multirow{4}{*}{1} & 0.1 & 4.0793 & 4.8147 & 6.5878 & 11.3109 \\
\hline & 0.2 & 3.9976 & 4.6698 & 6.2521 & 10.2930 \\
\hline & 0.3 & 4.0452 & 4.6816 & 6.1548 & 9.8303 \\
\hline & 0.4 & 4.2860 & 4.9164 & 6.3583 & 8.2377 \\
\hline \multirow{4}{*}{10} & 0.1 & 3.4273 & 4.0397 & 5.5100 & 9.3908 \\
\hline & 0.2 & 3.3606 & 3.9208 & 5.2353 & 8.5733 \\
\hline & 0.3 & 3.4024 & 3.9333 & 5.1590 & 8.2046 \\
\hline & 0.4 & 3.6061 & 4.1322 & 5.3329 & 6.2411 \\
\hline \multirow{4}{*}{ Metal } & 0.1 & 3.0466 & 3.5955 & 4.9183 & 8.4400 \\
\hline & 0.2 & 2.9839 & 3.4853 & 4.6657 & 7.6840 \\
\hline & 0.3 & 3.0183 & 3.4931 & 4.5931 & 7.3465 \\
\hline & 0.4 & 3.1977 & 3.6686 & 4.7475 & 5.8376 \\
\hline
\end{tabular}

\section{CONCLUSIONS}

The following general conclusions are made from the present study considering various side-to-thickness ratios, volume-fraction indices, additional-mass amounts, cutout sizes and boundary conditions.

The frequency parameter decreases with the increase in the volume-fraction index irrespective of the boundary condition, side-to-thickness ratio, skew angle, cutout size and additional mass.

The effect of additional mass on the vibration of the FGM plate under the CFCF boundary condition is negligible.

The frequency parameter increases with the skew angle.

Under the CFCF boundary condition, the frequency parameter decreases with the increase in the cutout size.

\section{REFERENCES}

${ }^{1}$ J. N. Reddy, Analysis of functionally graded plates, Int. J. Numer. Meth. Eng., 47 (2000), 663-684, doi:10.1002/(SICI)10970-207 (20000110/30)47

${ }^{2}$ S. Abrate, Free vibration buckling and static deflections of functionally graded plates, Compos. Sci. Technol., 66 (2006), 2383-2394, doi:10.1016/j.compscitech.-2006.02.032

${ }^{3}$ B. Uymaz, M. Aydogdu, Three-dimensional vibration analysis of functionally graded plates under various boundary conditions, J. Reinf. Plast. Compos., 26 (2007), 1847-1863, doi:10.1177/ 2F0731684407081351

${ }^{4} \mathrm{H}$. Matsunaga, Free vibration and stability of functionally graded plates according to a 2D higher order deformation theory, Compos. Struct., 82 (2008), 499-512, doi:10.1016/j.compstruct.2007. 01.030

${ }^{5}$ X. Zhao, Y. Y. Lee, K. M. Liew, Free vibration analysis of functionally graded plates using the element-free kp-Ritz method, J. Sound Vib., 319 (2009), 918-939, doi:10.1016/j.jsv. 2008.06.025

${ }^{6}$ M. E. Fares, M. Kh. Elmarghany, D. Atta, An efficient and simple refined theory for bending and vibration of functionally graded plates, Compos. Struct., 91 (2009), 296-305, doi:10.1016/j.compstruct.2009.05.008

${ }^{7}$ M. N. A. G. Taj, A. Chakrabarti, A. H. Sheikh, Analysis of functionally graded plates using higher order shear deformation theory, Appl. Math. Model., 37 (2013), 8484-8494, doi:10.1016/j.apm.2013. 03.058

${ }^{8}$ G. Taj, A. Chakrabarti, Static and dynamic analysis of functionally graded skew plates, J. Eng. Mech., 139 (2013), 848-857, doi:10.1061-/(ASCE)EM.1943-7889.0000523

${ }^{9}$ K. Asemi, S. J. Salami, M. Salehi, M. Sadighi, Dynamic and static analysis of FGM skew plates with 3D elasticity based graded finite element modeling, Lat. Am. J. Solids Struct., 11 (2014), 504-533, doi:10.1590/S16797825201-4000300008

${ }^{10} \mathrm{G}$. Aksu, R. Ali, Determination of dynamic characteristics of rectangular plates with cutouts using a finite difference formulation, J. Sound Vib., 44 (1976), 147-158, doi:10.1016/0022-460X(76) 90713-6

${ }^{11}$ R. Ali, S. J. Atwal, Prediction of natural frequencies of vibration of rectangular plates with rectangular cutouts, Comput. Struct., 12 (1980), 819-823, doi:10.1016-/00457949(80)90019-X

${ }^{12}$ J. N. Reddy, Large amplitude flexural vibration of layered composite plates with cutouts, Journal of Sound and Vibration, 83 (1982), 1-10, doi:10.1016/S0022460X-(82)80071-0

${ }^{13}$ M. Huang, T. Sakiyama, Free vibration analysis of rectangular plates with various hole shapes, J. Sound Vib., 226 (1996), 769-786, doi:10.1006/jsvi.1999.2313

${ }^{14}$ M. Janghorban, A. Zare, Thermal effect on free vibration analysis of functionally graded arbitrary straight-sided plates with different cutouts, Lat. Am. J. Solids Struct., 8 (2011), 245-257, doi:10.1590/ S1679-78252011000300003

${ }^{15}$ T. Mori, K. Tanaka, Average stress in matrix and average elastic energy of materials with misfitting inclusions, Acta Metall., 21 (1973), 571-574, doi:10.1016/0001-6160(73)90064-3 